\title{
Tadeusz Pieronek
}

\section{Reforma Kongregacji św. Oficjum}

Prawo Kanoniczne : kwartalnik prawno-historyczny 11/3-4, 19-35

1968

Artykuł został zdigitalizowany i opracowany do udostępnienia w internecie przez Muzeum Historii Polski w ramach prac podejmowanych na rzecz zapewnienia otwartego, powszechnego i trwałego dostępu do polskiego dorobku naukowego i kulturalnego. Artykuł jest umieszczony w kolekcji cyfrowej bazhum.muzhp.pl, gromadzącej zawartość polskich czasopism humanistycznych i społecznych.

Tekst jest udostępniony do wykorzystania w ramach dozwolonego użytku. 
KS. TADEUSZ PIERONEK

\section{REFORMA KONGREGACJI SW. OFICJUM}

Treść: Wstęp; I. Przyczyny reformy, II. Realizacja reformy, III. Stan obecny: cel reformy, zmiana nazwy, skład osobowy, zadania i kompe. tencja, sposób postępowania, Zakończenie.

\section{Wstęp}

Konstytucją Licet ab initio pap. Paweł III w dniu 21 lipca 1542 r. mianował sześciu kardynałów inkwizytorami generalnymi w Kurii Rzymskiej i na Italię, powierzając im troskę o sprawy wiary na tym terenie ${ }^{1}$.

Powstałej w ten sposób nowej instytucji, która stała się początkiem dzisiejszej Kongregacji Nauki Wiary, nie należy mieszać ani $z$ trybunałami średniowiecznej Inkwizycji, której działalność wygasła $\mathrm{z}$ początkiem XVI w., ani $\mathrm{z}$ osławioną Inkwizycją Hiszpańską, zależną wprawdzie od papiestwa, ale nie będącą centralnym organem władzy kościelnej i posiadającą w dużej mierze charakter narodowy hiszpański ${ }^{2}$.

Instytucja stworzona przez pap. Pawła III jest historycznie i hierarchicznie pierwszą spośród Kongregacji rzymskich. W ciągu wieków swego istnienia ulegała ona różnym przemianom, które dotyczyły jej nazwy, struktury wewnętrznej, zakresu kompetencji i sposobu postępowania.

1 Bullarium diplomatum et privilegiorum sanctorum Romanorum pontificum Taurinensis editio, Augustae Taurinorum 1860, t. 6, s. $344-346$.

$2 \mathrm{Naz}$ R., Saint Office, w: Dictionaire de droit cananique, Paris 1957, t. 6, kol. 1071; S a ndri L., Congregazioni Romane, w: Enciclopedia Cattolica, t. 4, Roma 1950, kol. 313; M o 11 a t G., Inquisizione, w: Enciclopedia Cattolica, t. 7, Roma 1951, kol. 43 - 49 . 
Pap. Pius IV w Konstytucji Pastoralis officii z 14 października 1562 r. rozszerzył jej kompetencje na cały Kościół i poddał jej jurysdykcji wszystkich, nie wyłączając kardynałów ${ }^{3}$, w Konstytucji zaś Romanus Pontifex z dnia 7 kwietnia 1563 r. zastrzegł dla papieża jej przewodnictwo ${ }^{4}$.

Pierwszy wielki reformator Kurii Rzymskiej, pap. Sykstus V, w Konstytutcji Immensa aeterni Dei z dnia 11 lutego 1587 r., nazwał ją oficjalnie Kongrecją Swiętej Inkwizycji ${ }^{5}$, potwierdził jej dotychczasowy zasięg terytorialny, a wyjął spod jej jurysdykcji sprawy dotyczące kardynałów ${ }^{6}$.

W tym stanie Kongregacja ta, ciągle zwiększając swe kompetencje ${ }^{7}$, przetrwała aż do następnej zasadniczej reformy Kurii Rzymskiej, której dokonał pap. Pius X Konstytucją Apostolską Sapienti consilio w dniu 20 czerwca $1908 \mathrm{r}^{8}$ Odtąd Kongregacja nosiła już urzędowo, od dawna będącą w użyciu nazwę Kongregacji Swiętego Oficjum, a jej uprawnienia, uwzględniając zmiany wprowadzone przez pap Benedykta XV w Motu Proporio Alloquentes z 25 marca 1917 r. ${ }^{9}$, zgodnie z którymi utworzono przy niej specjalną Sek-

$s, \ldots$ vos ceterosque quos deinceps addi, aut succedere in eodem officio contigerit... non per Italiam modo, sed etiam extra Italiam per omnes christiani nominis provincias, regiones et loca, apostolica auctoritate, tenore praesentium, motu proprio, confirmamus et, quatenus opus sit, de novo constituimus deputamus, et in quoscumque Lutheranae, Zuinglianae, Calvinianae, Anabaptistarum et alarum quarumvis haeresum sectatores, aut etiam a fide apostatas... cuiuscumque gradus, ordinis, conditionis et dignitatis sint, etiam si episcopali, archiepiscopali, primatiali et patriarchali dignitate aut cardinalatus honore sint praediti, atque etsi regia dignitate praefulgeant, inquirendi, et contra eos... procedendi" - Bull. Rom. Taur. t. 7, s. 237.

4 ,...processum omnem nobis, ut ad sententiae, quae iusta visa fuerit, prolationem devenire possimus, in consistorio nostro secreto referant" Bull. Rom. Taur., t. 7, s. 251.

5 ,Congregationem sanctae Inquisitionis haereticae pravitatis, magna praedecessorum providentia, tamquam firmissimum catholicae fidei propugnaculum in Urbe institutam, cui, ob summam rei gravitatem, Romanus Pontifex praesidere solet nos quoque confirmamus et corroboramus" - Bull. Rom. Taur., t. 8, s. 987.

- ,...non solum in Urbe et Statu temporali, nobis et huic Sanctae Sedi subiecto, sed etiam in universo terrarum orbe, ubi christiana viget religio, super omnes patriarchas, primates, archiepiscopos et alios inferiores..."-Bull. Rom. Taur., t. 8, s. 987.

${ }^{7} \mathrm{~N}$ avarrete U., Commentarium, w: Periodica de re morali canonica liturgica, fasc. $2-3$, (1966), s. 619-622.

- AAS 1 (1909) 7 - 19.

- AAS 9 (1917) 167. 
cję Indeksu ${ }^{10}$, przeszły w całości do norm Kodeksu Prawa Kanonicznego ${ }^{11}$.

\section{Przyczyny reformy}

Struktura Kongregacji Sw. Oficjum, zwłaszcza zaś sposób jej postępowania spotykały się z krytyką od dawna ${ }^{12}$, co dało nawet powód. pap. Piusowi XII do oficjalnego wystąpienia w jej obronie ${ }^{13}$. Niezadowolenie jednak narastało i znalazło swój wyraz zarówno we wnioskach zgłoszonych $\mathrm{w}$ tej sprawie na Sobór, jak i w głosach uczestników Vaticanum II na auli soborowej i poza nią.

We wnioskach przesłanych do Rzymu w związku z zapowiedzianym Soborem domagano się, by Sw. Oficjum zostało dostosowane do mentalności naszych czasów ${ }^{14}$, tzn. by działało jawnie ${ }^{15}$, podając motywy swych decyzji ${ }^{16}$, by wyrzekło się zbytniej podejrzliwości ${ }^{17}$, by w swym postępowaniu stosowało ewangeliczną zasadę de correptione fraterna ${ }^{18}$, karało fałszywych donosicieli, pozostawiło wolność badaniom naukowym i było raczej instytucją o charakterze duszpasterskim niż mścicielem prawa, w myśl zasady podanej już w kan. 2214, § 2: „meminerint se esse pastores non percussores" ${ }^{19}$, oraz by popierało studia teologiczne przez organizowanie kongresów naukowych, wydawanie książek i temu podobne akcje ${ }^{20}$. Przestarzały sposób postępowania ${ }^{21}$ winien być zreformowany ${ }^{22}$ bo daje powód wrogom Kościoła do atakowania go ${ }^{23}$. Konsultorzy $\mathbf{S w}$. Oficjum nie mogą się uważać za wszystko wiedzących i nie mogą oceniać ze znawstwem wszelkich spraw,

10 Sekcję tę utworzono przy Sw. Oficjum w miejsce zniesionej Kongregacji Indeksu. Początek zniesionej przez pap. Benedykta XV Kongregacji dal pap. Sukstus V - por. Bull. Rom. Taur., t. 8, s. 900.

11 kan. $247, \S 1-5$.

12 Por. np. Pich on Ch., Le Vatican, Paris 1960, s. $251-278$.

13 Discorsi e radiomessaggi di Sua Santita. Pio XII, Tipografia Poliglotta Vaticana, t. 8, s. $263-264$.

14 ADCOV (= Acta et documenta Concilio Oecumenico Vaticano II apparando, Typis Polyglottis Vaticanis 1960, t. II, II, s. 510; 494, 500.

15 ADCOV, t. II, II, s. 486.

16 ADCOV, t. II, II, s. 510.

17 ADCOV, t. II, V, s. 313.

18 ADCOV, t. II, s. 494, 500, 510.

19 ADCOV, t. II, V, s. 313.

20 ADCOV, t. II, III, s. 558.

21 ADCOV, t. II, II, s. 118.

22 ADCOV, t. II, II, s. $346-347$; t. II, V, s. $313-314$.

23 ADCOV, t. II, II, s. 118. 
ze wszystkich zakątków świata ${ }^{24}$. Najwięcej zarzutów czyniono Św. Oficjum $z$ tego powodu, że autorom, których książki są badane przez tę Kongregację, nie daje się możliwości obrony, co jak wiadomo jest naruszeniem zasad prawa natury ${ }^{25}$. Poważne i liczne zarzuty spotkały też Sekcję Indeksu książek zakazanych działającą w ramach $\mathbf{S} w$. Oficjum ${ }^{26}$.

Dwa tylko są w tych materiałach glosy przychylne Sw. Oficjum, z których jeden domaga się ścisłego nadzoru nad tymi katolikami, którzy wykorzystują swe wyznanie by zyskać głosy wyborców, a $w$ rzeczywistości nie maja $z$ wiarą nic wspólnego ${ }^{27}$, drugi domaga się od biskupów składania sprawozdań Sw. Oficjum z okazji visitatio liminum ${ }^{28}$.

\section{Realizacja reformy}

Powyższe postulaty znalazły odbicie już w pierwszych schematach soborowych opracowanych przez Komisję De episcopis et de dioeceseon regimine. Tekst schematu zatytułowanego De rationibus inter episcopos et SS. Curiae Romanae Congregationes, liczący poza wstępem 6 tytułów podzielonych na 32 paragrafy, został. zatwierdzony przez Komisję Centralną w dniach od 25 września do 7 października $1961 \mathrm{r}^{29}$

Jeszcze przed otwarciem Soboru podniosły się głosy, że reformę Kurii Rzymskiej należy zostawić jej samej i papieżowi, stanowi ona bowiem organ administracyjny będący w służbie samego papieźa i nie zależy od Soboru ${ }^{30}$. Stąd też w schemacie dekretu $D e$ s. 263.

24 Ibidem.

${ }^{25}$ ADCOV, t. II, I, s. 151 ; t. II, II, s. $118,486,494.500,510$; t. II, IV,

${ }_{26}^{26}$ ADCOV, t. II, III, s. $346-347$; t. II, I, s. 419; t. II, II, s. 23 i 310 ;

t. IV, I, s. 45 i 156 ; t. II, V, s. $313-314$.

27 ADCOV, t. II, III, s. 490 .

${ }^{28}$ ADCOV, t. II, V, s. 50.

${ }^{29}$ Schema decreti De rationibus inter episcopos et SS. Curiae Romanae Congregationes propositum a Commissione de episcopis et de dioeceseon regimine, Typis Polyglottis Vaticanis 1961; por. także: Il Concilio Vaticano II, L'annunzio e la preparazione 1959 - 1962, t. I, cz. II ed. di Giovanni Caprile S.J. ,La Civilatà Cattolica" Roma (1966), s. 332-333, oraz: Caprile G., L'iter del decreto, w: Il Concilio Ecumenico Vaticano II, ed speciale L,Osservatore della Domenica, (Città del Vaticano 1966), s. 78.

${ }^{30}$ Il Conc. Vat. II, ed La Civiltà Cat., t. I, cz. II, s. 385-386 gdzie znajduje sie streszczenie artykułu bpa Waltera Kampe $\mathrm{z}$ Limburga pt. Prima del Concilio: pubblicità giusta e publicità sbagliata, opublikowanego w biuletynie Agencji Kipa, dnia 13 lutego 1962. 
episcopis ac de dioecesium regimine z 1963 r. znajdujemy notatkę, że na tematy Kurii nie będzie debaty na soborowych kongregacjach generalnych, wnioski zaś można składać na piśmie u Sekretarza Generalnego Soboru, który przekaże je bądź Komisji Rewizji Kodeksu Prawa Kanonicznego, bądź dykasteriom Kurii Rzymskiej do opracowania ${ }^{31}$.

Pap. Paweł VI nadal jednak całej sprawie nowy bieg w swym przemówieniu do pracowników Kurii Rzymskiej w dniu 21 września 1963 r. w którym wskazał na potrzebę reformy i nakreślił jej kierunki ${ }^{32}$.

Sobór zajął się zagadnieniem na czterech kongregacjach generalnych (od 60 do 63) w dniach od 5 do 8 listopada $1963 \mathrm{r}$. Twarde słowa pod adresem $\mathbf{S} w$. Oficjum padly z ust. kard. Fringsa, arcybiskupa Kolonii $\mathrm{w}$ ostatnim dniu debaty na ten temat. Jego zdaniem trzeba odnowić cały sposób postępowania Kongregacji rzymskich, dobrze rozróżniając między drogą postępowania administracyjnego a sądowego, co należy zastosować również do Ŝw. Oficjum, którego procedura nie odpowiada naszym czasom i jest dla wielu przyczyną zgorszenia. Nikt w rzeczy samej nie może być potępiany nie będąc uprzednio wysłuchanym i nie posiadając możliwości obrony i poprawy. Autorom należy dać okazję wypowiedzenia się na temat tego co myślą i na temat ich książek.

Ówczesny sekretarz Sw. Oficjum kard. Ottaviani, odpowiadając na zarzuty, ostro i uroczyście zaprotestował przeciwko tym oskarżeniom. Nie należy zapominać, powiedział, że prefektem Św. Oficjum jest sam papież. Wypowiedziana krytyka pochodzi ze słabej znajomości, by nie użyć słowa mocniejszego, procedury tej Kongregacji. Nikt nigdy nie jest oskarżany, sądzony i potępiany bez uprzedniego dochodzenia, prowadzonego przy pomocy kompetentnych konsultorów i doświadczonych specjalistów. Ponadto wszystkie decyzje $\mathbf{S} w$. Oficjum są osobiście zatwierdzane przez papieża, stąd wszelka krytyka zwraca się w tym wypadku i ku Zastępcy Chrystusa ${ }^{33}$.

31 Sacr. Oec. Conc. Vat. Sec., Schemata constitutionum et decretorum de quibus disceptabitur in Concilii sessionibus, Schema decreti De episcopis ac de dioecesium regimine, Typis Polglottis Vaticanis 1963, s. 28 W przypisie.

32 AAS 55 (1965) 793.

3s Svidercoschi G., Storia del Concilio, Milano (1967), s. 284-285; Il Conc. Vat. II, Secondo Periodo 1963-1964, ed. La Civiltà Cat., t. III. s. 212, 214-215; L a u r e n t in R., L'enjeu du Concile, Bilan de la $3 \dot{e}$ session, Paris (1964), s. 120-130; W e n ge r A., Vatican II Chronique de la deuxième session, Paris (1964), s. 147-148. 
W wywiadzie prasowym opublikowanym $\mathrm{m}$. in. we Whoszech i we Francji, kard. Ottaviani wyjaśnił sposób postępowania Sw. Oficjum: „Opinie wygłaszane dziś o Sw. Oficjum grzeszą przede wszystkim anachronizmem, ponieważ osądza się tę Kongregację jakgdyby była ona jeszcze dawną Inkwizycją. Tymczasem chodzi o organizm całkowicie nowoczesny, postępujący według wszelkich regul roztropności, by dojšć do decyzji nacechowanych prawdą i sprawiedliwością. To, że procedura Sw. Oficjum jest strzeżona sekretem, ma miejsce przede wszystkim dla ochrony dobrego imienia i publicznej opinii osób będących przedmiotem procesu. Między tymi osobami mogą być i niewinni, których uwalnia się od oskarżenia; ich opinia broniona jest sekretem przeciwko cieniowi jaki rzucałaby na nie wiadomość o tym, że były postawione przed sądem Najwyższego Trybunału. To samo odnosi się do autorów książek, których opinia mogłaby ucierpieć, gdyby się wiedzialo że ich książki są badane przez Sw. Oficjum. Tak więc ci wierni, którzy są posluszni władzy kościelnej i idą za jej wskazaniami, mogliby stracić szacunek dla osób, których sprawy toczą się w tym dykasterium, podczas gdy można te osoby uznać, i często tak jest, za wolne od jakichkolwiek zarzutów ze strony $\mathbf{S w}$. Oficjum. W procesach, oskarżony, którego nie uważa się za winnego dokąd się mu winy nie udowodni, jest wysłuchany i przed podpisaniem protokołu zeznań może czynić wszelkie zastrzeżenia, jeśli notariusz nie zapisał wiernie jego myśli. W sprawach książek na ogół zasięga się zdania ordynariusza, na temat działalności pisarskiej i wydawniczej autora. Przedmiotem osądu jest zresztą jego książka drukowana, zatem per se byłoby rzeczą zbyteczną dowiadywać się co autor myśli. Nie to co myśli, lecz to co napisal jest przedmiotem osądu, a szkoda dla dusz, która może wyniknąć z jakiejś książki, zależy od tego co zostało napisane, nie zaś od tego co myślal autor. Badanie jakiejś książki zakłada przede wszystkim uprzednią ocenę kancelarii $\mathbf{S} w$. Oficjum decydującej o tym, czy książka warta jest rozważenia. W wypadku oceny negatywnej, rzecz kończy się przez reponatur (termin techniczny oznaczający według stylu Kurii złożenie sprawy do archiwum), w wypadku oceny pozytywnej, congresso postanawia powierzyć badanie publikacji dwom biegłym, ץosługującym się tym samym językiem co autor, którzy przygotowują niezależnie relacje dotyczące omawianego pisma. Relacje te są najpierw badane i dyskutowane przez jakieś dwudziestu konsultorów rekrutujących się $z$ różnych narodowości i z profesorów uczelni rzymskich, a następnie w drugiej instancji, przez plenarne zgromadzenie dziesięciu kardynałów członków Sw. Oficjum. Ci proponują swoje rozwiązanie do zatwierdzenia Ojcu Swiętemu, 
który uprzednio otrzymal obydwie wydane drukiem relacje biegłych. Widać $z$ tego wszystkiego, że kiedy jakaś sprawa dochodzi do Ojca Swiętego, by jako prefekt $\$$ w. Oficjum wypowiedzial na jej temat ostatnie słowo, przeszła ona już przez różne instancje badania. I oto dlaczego, w pewnych wypadkach, decyzje Sw. Oficjum wychodzą $z$ poważnym opóźnieniem w stosunku do daty ukazania się książki. Ponadto ostatnimi czasy, i jest to nowa praktyka Sw. Oficjum, unikano potępienia jak tylko to było możliwe. Uważano za rzecz lepszą porozumienie się z autorem za pośrednictwem biskupa, by wycofał ze sprzedaży oskarżone dzieło, lub przynajmniej postarał się o nowe, poprawione wydanie".

Odpowiadając na dalsze pytania dotyczące tajności procedury kard. Ottaviani wyjaśnił: „Sekret jest wymagany także i dlatego, by zostawić pełną wolność konsultorom i sędziom, którymi są kardynałowie, a na których $\mathrm{w}$ przeciwnym wypadku wywieranoby presję $\mathrm{w}$ jednym lub $\mathrm{w}$ drugim kierunku. W pewnych wypadkach usiłowano wpływać na decyzje Św. Oficjum uciekając się aż do drogi dyplomatycznej. Można zatem zrozumieć, w jaki sposób sekret, broniąc dobrej opinii zainteresowanych osób, zabezpiecza także niezależność sędziów. Przy okazji warto zwrócić uwagę, że jeśli ktoś pisze książkę, przez to samo poddaje się osądowi jakiegokolwiek krytyka, który może ją ocenić nieprzychylnie w każdym czasopiśmie, bez obowiązku wysłuchania zainteresowanego" ${ }^{34}$.

Starcie Frings - Ottaviani wywołało szeroką dyskusję wokół racji przytoczonych przez dyskutantów. Obrona Sw. Oficjum wygloszona przez kard. Ottaviani nie przekonała. Najsilniejszym wydawał się być argument, że dotychczaowa procedura Sw. Oficjum miała obowiązek liczyć się z ludźmi, którzy stali za wciąganymi na Indeks książkami. Wielokrotnie zresztą Sw. Oficjum i za naszych dni działało hamująco na rozwój nauk teologicznych przez swoje interwencje, chociażby w stosunku do takich teologów jak $\mathrm{O}$. Lagrange, $\mathrm{O}$. de Lubac, czy $\mathrm{O}$. Congar ${ }^{35}$.

Owocem tych dyskusji $\dot{i}$ pisemnych wniosków stał się postulat. reformy Sw. Oficjum, który znajdujemy w Relacji do schematu De pastorali episcoporum munere in Ecclesia z 1964 r. Czytamy tam: „Najwyższą Kongrecję Sw. Oficjum należy odpowiednio zreformować i nazwać ją Kongregacją dla spraw wiary i obyczajów" 38. Ta sama Relacja zaleca jednak, by nie mówić w schema-

34 Podaję tłumaczenie $\mathrm{z}$ tekstu przytoczonego przez A. Wenger, dz. cyt., s. $150-153$.

${ }_{35} \mathrm{~L}$ a ur entin R., dz. cyt., s. $124-130$.

s6 Sacr. Oec. Conc. Vat. Sec., Schema decreti De pastorali episcoporum munere in Ecclesia, Typis Polyglottis Vaticanis 1964, s. 37. 
cie szczegółowo o reformie $\$$ w. Oficjum „bo zajmowanie się sprawami szczegółowymi nie należy do Soboru Powszechnego". Zalecenie takie było równoznaczne ze wskazaniem na Ojca Swiętego jako na jedynie kompetentnego w sprawach rozstrzygnięć szczególowych. W ostatecznej redakcji Dekret $O$ pasterskich zadaniach biskupów $w$ Kościele zawiera tylko ogólne wskazania dotyczące Kurii Rzymskiej ${ }^{37}$, sprawę reformy zostawiając papieżowi.

Jeszcze przed definitywnym przyjęciem tego Dekretu, co miało miejsce w dniu 28 października 1965 r., w jednej ze swych homilii wygłoszonej w czasie IV sesji Soboru w dniu 18 października tegoż roku, pap. Paweł VI zapowiedział rychłe wydanie norm reformujących Sw. Oficjum ${ }^{38}$.

Trzy tygodnie później, 7 grudnia 1965 r. wyszło Motu Proprio Pawła VI Integrae servandae, zmieniające nazwę, strukture i sposób postępowania Sw. Oficjum ${ }^{39}$. Po niespełna dwóch latach, inne Motu Proprio Pro comperto sane z dnia 5 sierpnia 1967 r. ${ }^{40}$ wprowadziło dalsze zmiany do zreformowanej Kongregacji, w związku z powołaniem biskupów diecezjalnych na członków Kurii Rzymskiej. Wreszcie Konstytucja Apostolska Regimini Ecclesiae universae $\mathrm{z}$ dnia 15 sierpnia $1967 \mathrm{r}^{41}$ ostatecznie reformę potwierdziła, uzupełniając ją w niektórych szczegółach dużej wagi.

\section{Stan obecny}

Cel reformy. Motu Proprio Integrae servandae, jak większość tego rodzaju dokumentów papieskich ukazujących się po Soborze Watykańskim II, dzieli się na dwie części: wyjaśniającą i normatywną. Część druga, zawierająca szczegółowe przepisy ujęta jest w 12 norm, pierwsza część natomiast zmierza w zasadzie do uzasadnienia potrzeby reformy i nakreśla jej cel.

Ojciec Swięty tłumaczy, że depozyt wiary powierzony przez Boga Biskupom Rzymskim, zostal przez nich przekazany nietknięty aż do naszych czasów. Kościół jednak, chociaż przez Boga założony, składa się z ludzi i wśród nich działa. By więc papież

${ }^{37}$ Dekret Christus Dominus, nr 9 i 10.

38 Sacrosanctum Oecumenicum Concilium Vaticanum II, Constitutiones decreta declarationes, Cura et studio Secretariae Generalis Concilii Oecumenici Vaticani II, (Typis Polyglottis Vaticanis 1966), s. $1050-1051$.

${ }_{39}$ Ukazało się ono najpierw w L'Osservatore Romano $z$ dnia 6-7 grudnia 1965 r., a następnie w AAS 57 (1965) 952-955.

40 AAC 59 (1967)

41 AAS 59 (1967) 
mógł lepiej Kościołem zarządzać, musi się posłużyć organem administracyjnym jakim jest Kuria. Kreśląc następnie historię tego organu, Ojciec Sw. wskazuje na konieczność zmian, jakim ze względu na zmieniające się warunki życia musiała $w$ ciągu wieków ulegać i Kuria Rzymska.

Zmianom tym podlegała i Kongregacja Swiętego Oficjum, reformowana przez papieży $\mathrm{w}$ miarę potrzeb.

Po zasięgnięciu rady kardynałów i biskupów, papież zdecydował się i dziś na rozpoczęcie refomy Kurii, zaczynając od tej Kongregacji, której są powierzone sprawy najważniejsze, a mianowicie „nauka wiary i obyczajów, oraz sprawy z tą nauką najściślej związane" 42. „Ponieważ zaś - mówi pap. Paweł VI - miłość „precz wyrzuca bojaźń" ( $2 \mathrm{~J} 4,18)$, obronie wiary zaradzi się obecnie lepiej przez dzieło popierania doktryny $w$ taki sposób, by przez poprawianie błędów i łagodne przywoływanie do dobra błądzących, głosiciele Ewangelii nabierali nowych sił. Poza tym postęp kultury ludzkiej, którego na gruncie religijnym zaniedbać nie wolno, sprawia, że wierni pełniej i z większą milością idą za wskazaniami Kościoła, jeśli - o ile to jest możliwe - wskaże się im jasno motywy definicji i praw w dziedzinie wiary i obyczajów. Tak więc - kontynuuje papież - by ta święta Kongregacja na przyszłość lepiej wykonywała swe zadanie wspierania nauki i działolności Kościoła w najważniejszych dziejach apostolstwa" ${ }^{43}$, ustala się normy reformujące Kongregację $\mathbf{S w}$. Oficjum.

$\mathrm{Z}$ mi a n a n z wy. „Nazywana dotąd Sw. Kongregacją $\$$ w. Oficjum będzie się nazywać na przyszlość Kongregacją Nauki Wiary ${ }^{44}$.

Wprawdzie ,de nominibus non est curandum", niemniej jednak, jeśli zmianie ulega nie tylko nazwa, ale i cała struktura, której określeniu służyła, nowa nazwa ma niewątpliwy sens. $Z$ pewnością ta nowa nazwa bardziej odpowiada mentalności naszych czasów i nie budzi niezbyt miłych skojarzeń z Inkwizycją ${ }^{46}$. MPIS opuszcza przy nowej nazwie przymiotnik sacra i to zarówno w tekście normy pierwszej odnoszącej się wprost do zmiany nazwy, jak i w normach 10,11 i 12 , posługujących się określeniem

42 AAS 57 (1965) 954; Por. Zizol a G., Audacia e limiti della Curia romana riformata, w: Il Regno, Documentazione cattolica, n. 145/18 (1967), s. 343.

43 AAS 57 (1965) 953.

44 MPIS (= Motu Proprio Integrae servandae), n. 1.

45 A lvarez - Menéndez S., La reforma de la Congregacion. del Santo Oficio, w: Revista Espanola de Derecho Canonico, 61 (1966), s. 106-107. 
Kongregacja. Przymiotnik ten znajduje jednak ponownie w CAREU, tak przy nazwie Kongregacji Nauki Wiary, jak i przy nazwach pozostałych Kongregacji. To samo można stwierdzić w MPPCS. Stąd też pełna nazwa omawianego dyskasterium brzmi: Sacra Congregatio pro Doctrina Fidei, Swięta Kongregacja Nauki Wiary.

Przymiotnik suprema został już celowo opuszczony przy reformie Fiusa $\mathrm{X}$, ale utrzymał się $\mathrm{w}$ praktyce do tego stopnia, że często zastępowano nim calkowicie pelną nazwę Sw. Oficjum aż do reformy Pawła VI ${ }^{46}$. Ponieważ CAREU stanowi że „Kongregacje pod względem prawnym są sobie równe" ${ }^{47}$, dlatego pierwszeństwo Kongregacji Nauki Wiary mogłoby dziś być uzasadnione jedynie wagą spraw należących do jej kompetencji.

Sklad os obowy. Pod tym względem od czasu wydania MPIS zaszły już zasadnicze zmiany. Podczas gdy MPIS zachowywało w zasadzie przepis kan. 246 i 247 , § 1 stanowiąc że „na czele Kongregacji stoi papież, a kieruje nią kardynal sekretarz przy pomocy asesora, sybstytuta i promotora sprawiedliwości" ${ }^{48}$ o tyle CAREU podaje zasadę ogólną, zmieniającą kan. 246 o ile dotyczył papieża, oraz przepis szczegółowy dotyczący Kongregacji Nauki Wiary. Zasada ogólna mówi, że „Kongregacjom przewodniczy i kieruje nimi kardynal prefekt" 49 i że ,kardynała prefekta wspomaga sekretarz wybrany przez papieża, podsekretarz mianowany także przez papieża i inni urzędnicy" ${ }^{50}$. Przepis szczegółowy natomiast postanawia, że Kongregacji Nauki Wiary „przewodniczy kardynal prefekt, wspomagany przez sekretarza, podsekretarza i przez promotora sprawiedliwości" 51. Tak więc papież zrezygnowal $z$ wiekowej praktyki przewodniczenia niektórym Kongregacjom Rzymskim, w wśród nich także Kongregacji Nauki Wiary.

Obok kardynała prefekta, sekretarza i podsekretarza, w skład Kongregacji Nauki Wiary wchodzą kardynałowie wybierani przez papieża ${ }^{52} \mathrm{w}$ liczbie bliżej nie określonej, oraz siedmiu biskupów diecezjalnych, wskazanych przez Konferencje Episkopatu i zainteresowane Kongregacje, a mianowanych przez papieża ${ }^{53}$.

${ }_{46}$ Navarrete, dz. cyt., s. 624; por. Sacr. Oec. Conc. Vat. Sec., Schema decreti De pastorali episcoporum munere in Ecclesia, s. 37. 47 CAREU (= Constitutio Apostolica Regimini Ecclesiae universae), n. $1, \S 2$.

48 MPIS, n. 2.

${ }^{49}$ CAREU, n. $2, \S 3$.

50 CAREU, n. $2, \S 4$.

31 CAREU, n. 30.

52 CAREU, n. $2, \S 1$.

54 MPPCS (= Motu Proprio Pro comperto sane), n. 4 i 5. 
Urzędników Kongregacji stanowią: promotor sprawiedliwości ${ }^{54}$, mianowany zapewne przez kardynala prefekta, oraz obroncy stron, czyli adwokaci, potrzebujący do sprawowania swych funkcji w Kongregacji, jej specjalnego upoważnienia ${ }^{55}$.

Sklad osobowy uzupełniają konsultorzy, wybierani przez papieża wśród biskupów, kapłanów diecezjalnych i zakonnych, oraz katolików świeckich całego świata ${ }^{56}$, a także specjaliści, eksperci, wybierani przez papieża zwłaszcza spośród profesorów uniwersytetów ${ }^{57}$.

Kardynałowie, biskupi diecezjalni jako członkowie Kongregacji, sekretarz i konsultorzy, pełnią urząd przez pięć lat, Kardynałowie jednak i sekretarz mogą być nawet wielokrotnie na tym stanowisku zatwierdzani i stanowisko ich wymaga potwierdzenia w ciągu trzech miesięcy po wyborze nowego papieża, nawet jeśli mianowani przez poprzednika, nie pełnili swego urzędu przez pięć lat ${ }^{58}$. Dla konsultorów jest możliwe zatwierdzenie tylko na drugie pięciolecie ${ }^{59}$, a w stosunku do biskupów diecezjalnych Konstytucja nie przewiduje możliwości przedłużenia ich pracy w Kongregacji $\mathrm{i}$ to jak się wydaje nie tylko $w$ tej samej $w$ której byli ostatnio zatrudnieni przez pięć lat, ale w ogóle w żadnej innej ${ }^{60}$.

Niektóre stanowiska, lub przynajmniej nazwy stanowisk zniknęły z Kongregacji Nauki Wiary zupełnie. Tak więc nie spotykamy już określenia ,inkwizytorzy generalni" stosowanego do kardynałów przydzielonych przez papieża do Sw. Oficjum ${ }^{61}$, zniknęli kwalifikatorzy, a także urząd komisarza i tzw. towarzyszy, stale dotąd zarezerwowane przedstawicielom zakonu dominikańskiego ${ }^{62}$.

54 MPIS, n. 2; CAREU, n. 30.

55 MPIS, n. 8; CAREU, n. 36.

56 CAREU, n. 5, § 1 ; MPIS, n. 10; CAREU, n. 38.

57 MPIS, n. 10; CAREU, n. 38.

58 CAREU, n. 2, 85.

58 CAREU, n. 5, § 2.

60 Powyższa interpretacja MPPCS, n. 6 wydaje się znajdować uzasadnienie przede wszystkim $w$ celu dla urzeczywistnienia, którego Ustawodawca wydal tę normę, a mianowicie ,by Swięte Kongregacje mogły się wzbogacać doświadczeniem członków zawsze nowych i sprawnych, ich urząd trwać będzie pięć lat". Ponadto MPPCS nic nie mówi o możliwości przedłużenia kadencji biskupów diecezjalnych w Kurii Rzymskiej, Moźliwości nominacji tego samego biskupa na członka innej Kongregacji po upływie pierwszego pięciolecia MPPCS nie wyklucza.

61 Alvarez - Menéndez, dz. cyt., s. 111-113; Navarrete, dz. cyt., s. $640-642$..

62 A. d e B., La reforme du Saint - Office, w: Nouvelle Reuve Théologique, 88 (1966), s. 303 . 
Zadania i kompetencje. Określając rzeczowy i terytorialny zakres kompetencji Kongregacji Nauki Wiary MPIS i CAREU są ze sobą całkowicie zgodne, jeśli nie brać pod uwage nieistotnych różnic słownych. W stosunku zaś do kan. $247, \S 1$, określającego rolę Sw. Oficjum słowami: „strzeże nauki wiary i obyczajów", obydwa dokumenty papieskie wnoszą nowy element $\mathrm{W}$ postaci jasnego określenia wyłącznej kompetencji Kongregacji Nauki Wiary w stosunku do spraw nauki wiary i obyczajów oraz spraw $z$ wiarą związanych, a także $w$ formie dokładnego wytyczenia zakresu terytorialnego tej kompetencji. Obecne przepisy stanowią: „,Swięta Kongregacja Nauki Wiary ma za zadanie strzec nauki wiary i moralności $\mathrm{w}$ całym katolickim świecie" ${ }^{63}$ Wradza Kongregacji rozciągała się na cały katolicki świat już od czasów pap. Piusa IV, ale dopiero obecnie Ustawodawca tak jasno to sformułował. „Do niej należą - czytamy dalej w CAREU - wszystkie sprawy dotyczące nauki wiary i obyczajów, albo które $z$ tą wiarą się łączą" "64. W slowach „wszystkie sprawy” wyraźnie określona jest wylączność jurysdykcji Kongregacji Nauki Wiary we wskazanych sprawach.

Skuteczne działanie zreformowanej Kongregacji w obecnych warunkach życia wymaga nowych środków, dostosowanych do rnentalności współczesnego człowieka. Nic więc dziwnego, że nowe prawo podkreśla przede wszystkim pozytywne działanie Kongregacji. Jest to zresztą wynik nastawienia podyktowanego całemu Soborowi już przez pap. Jana XXIII w dniu otwarcia pierwszej sesji soborowej. „W chwili obecnej - powiedzial wówczas papież - Oblubienica Chrystusa woli raczej używać lekarstwa miłosierdzia, niż przywdziewać zbroję surowości. Uważa, że dzisiejszym potrzebom, lepiej zaradzi się przez bardziej szczegółowe wyjaśnianie treści nauki, niż przez potępianie" " ${ }^{6}$. Jeszcze jaśniej wyraził tę samą myśl pap. Paweł VI we wstępie do omawianego Motu Proprio Integrae servandae ${ }^{60}$.

Zgodnie ze wskazanym kierunkiem działania, Kongregacja, dla osiągnięcia swych celów ,bada nowe doktryny i nowe opinie w jakikolwiek sposób rozpowszechniane, inicjuje studia w tej materii, popiera kongresy naukowców" ${ }^{67}$.

${ }^{63}$ MPIS, n. 1; CAREU, n. 29.

${ }^{64}$ MPIS, n. 3; CAREU, n. 31.

65 Sacr Oec. Conc. Vat. II, Constitutiones decreta declarationes, Cura et studio Secretariae Generalis Concilii Oec. Vat. II, (Typis Polygl. Vat. 1966), s. $865-866$.

88 AAS 57 (1965) 953.

BI MPIS, n. 4; CAREU, n. 32 
Zadaniem Kongregacji pozostaje jednak nadal odrzucanie dok. tryn sprzecznych z zasadami wiary: „odrzuca te doktryny, które okazują się być sprzeczne $z$ zasadami wiary, jednak po wysłuchaniu okolicznych biskupów, jeśli są tym zainteresowani" 88.

Najwyższy organ powołany przez Kościół do czuwania nad czystością wiary, nie może być obojętny na szerzące się błędy, może jednak przeciwdziałać im w sposób zgodny bardziej niż dotychczas z mentalnością współczesnego człowieka, a więc skuteczniej. Kongregacja Nauki Wiary nie może dziś odrzucać błędów doktrynalnych samowolnie, lecz może to robić $\mathrm{w}$ porozumieniu $\mathrm{z}$ episkopatem tego miejsca, w którym taka doktryna się rozpowszechnia. Nowe prawo uwydatnia tu wyraźnie rolę Narodowych Kongregacji Episkopatu, chociaż wprost o nich nie mówi.

Przykładem nowego sposobu spełniania przez Kongregację jej obowiązków w stosunku do błędnych doktryn w dziedzinie wiary, może być List Konferencji Episkopatu „o szerzących się dziś błędnych i wieloznacznych poglądach" $\mathrm{z}$ dnia 24 lipca $1966 \mathrm{r}^{69}$, oraz polecenie utworzenia przy Konferencjach Episkopatu specjalnych Komisji Doktrynalnych, wydane dnia 23 lutego $1967 \mathrm{r}^{70}$ Zadaniem tych ostatnich, jest niesienie pomocy Kongregacji $w$ walce $z$ błędami doktrynalnymi, $m$. in. przez sugerowanie skutecznych przeciwko nim środków ${ }^{71}$.

Trzecim wreszcie sposobem którym posługuje się Kongregacja dla ochrony wiary, jest cenzura książek: „Pilnie bada wskazane jej książki i jeśli to jest wskazane odrzuca je, jednak po wysłuchaniu autora i dawszy mu prawo obrony także na piśmie, oraz nie bez uprzedniego zawiadomienia ordynariusza, tak jak to już było zastrzeżone w Konstytucji Benedytka XIV Sollicita ac provida" 72 .

Nowe to prawo nie powtarza za kanonem 247 , § 3 takich zwrotów jak „libros prohibere”, „dispensationes concedere”, ,ex officio inquirere", czy "scripta damnanda", stanowi jednak o możliwości odrzucenia określonych książek. Tego rodzaju cenzura jest

\footnotetext{
68 Ibidem.

${ }^{69}$ Nuntius Sacrae Congregationis pro Doctrina Fidei. 1 (1967), s. $17-19$.

70 Ibid., s. $15-16$.

$71, \ldots$.. Dicasterium exoptat ut prae primis ipsi per se Episcopi vel singulariter in coetu coadunati, pro munere et iure suo fidei custodiendae satagant utque ea quae censuerint notabile habere momentum, relate ad fidei morumque doctrinam, cum eadem $\mathbf{S}$. Congregatione communicent suggerentes etiam quae remedia, ad errorum forte evellendos, expedire in Domino videantur" - Nuntius, s. 16.

72 MPIS, n. 5; CAREU, n. 33.
} 
jednak obwarowana szeregiem ograniczeń. Książka może zostać odrzucona: a) jeśli to jest wskazane, b) po wysłuchaniu autora, c) po udzieleniu mu prawa obrony także na piśmie, oraz d) po uprzednim zawiadomieniu miejscowego ordynariusza.

We wszystkich tych klauzulach zabezpieczających naturalne prawo autorów do wlasnej obrony, oraz prawo ordynariusza miejscowego do zabrania głosu w sprawie, widać wpływ najmocniej bodaj podkreślanego przed Soborem postulatu pod adresem Sw. Oficjum, by nikogo nie potępiało bez uprzedniego umożliwienia mu obrony i poprawy.

Powołanie się na Konstytucję Apostolską pap. Benedykta XIV Sollicita ac provida, jest tu jakgdyby echem dyskusji soborowej, w której kard. Ottaviani w obronie Sw. Oficjum twierdził, że autorom daje się prawo obrony zgodnie $\mathrm{z}$ przepisem zawartym we wspomnianej Konstytucji, która przecież nie utraciła swej mocy prawnej. Podobny poglaad wyraził swego czasu i pap. Pius XII, również broniąc kierowanej przez siebie Kongregacji przed analogicznymi zarzutami ${ }^{73}$.

Następstwem nowych przepisów w zakresie cenzury książek, jest zniesienie Sekcji Cenzury Książek przy Kongregacji ${ }^{74}$, sam zaś Indeks, przestał obowiązywać $\mathrm{w}$ sensie przyjętym przez prawo kanoniczne dla tego słowa, o czym poinformowała Kongregacja Nauki Wiary w dniu 14 czerwca $1966 \mathrm{r}^{75}$, a nieco później, bo 15 listopada $1966 \mathrm{r}$. potwierdziła tę informację, rozstrzygając specjalnym dekretem, istniejące jeszcze $w$ tej sprawie wątpliwości ${ }^{76}$. Warto przy okazji zwrócić uwagę, że przepis kan. 247 , § 3, dotyczący udzielania przez Sw. Oficjum dyspens w stosunku do Indeksu, został jeszcze przed reformą tej Konstytucji odwolany w Motu Proprio Pastorale munus, gdzie władzę taką otrzymali biskupi ${ }^{77}$. Po wydaniu jednak MPIS i wycofaniu Indeksu, uprawnienie to stało się niecelowe.

Ostatnim środkiem jakim Kongregacja Nauki Wiary dysponuje w obronie wiary, jest według nowego prawa utrzymywanie przez nią kontaktów z Papieską Komisją Biblijną: „Popiera pożyteczne kontakty z Papieską Komisją Biblijną" " ${ }^{8}$. Wzajemna łączność ma

${ }^{73}$ Discorsi e radiomessaggi di Sua Santità Pio XII, Tipografia Poliglotta Vaticana, t. 8, s. 263-264.

${ }_{74}$ Już Annuario Pontificio 1966 r. Sekcja ta nie jest wymieniona przy Kongregacji Nauki Wiary.

75 AAS 58 (1966) 445.

76 AAS 58 (1966) 1186.

77 AAS 56 (1964) 11.

78 MPIS, n. 9; CAREU, n. 37. 
być podyktowana względami potrzeby i roztropności. Niewątpliwie przepis ten ma na oku względy ekumeniczne i ewentualne trudności, które w kwestiach źródel Objawienia może nasunąć postęp ekumenizmu.

W miejsce kan. $247, \S 3$, przyznającego Św. Oficjum kompetencje $\mathrm{w}$ sprawach przywileju Pawłowego, oraz dyspens od przeszkód małżeńskich odmiennego wyznania i różności wiary, nowe prawo podaje zwięzłą normę: „Do niej również należy rozpatrywanie od strony prawnej i faktycznej, spraw dotyczących przywileju wiary" ${ }^{79}$. Norma ta, zdaniem niektórych autorów „wydaje się wprost zawierać inne możliwości rozwiązywania małżeństwa niedopelnionego między ochrzczonymi, jeśli wymagałoby tego dobro wiary" ${ }^{80}$.

Z innych spraw, należących poprzednio do kompetencji Św. Oficjum, Kongregacja Nauki Wiary zachowała swe uprawnienia konsultowania spraw dotyczących ważności wyższych święceń i obowiązków z nich wynikających, gdyby zaszła potrzeba wysłuchania jej zdania $w$ tej sprawie ${ }^{81}$, oraz $w$ sprawach dotyczących postu eucharystycznego kapłanów odprawiających Mszę Ŝ. Dyspens jednak, przekraczających uprawnienia biskupów w tej ostatniej kwestii, udzielać może tylko Kongregacja Sakramentów ${ }^{82}$.

Nie uległ też zmianie zakres uprawnień Kongregacji Nauki Wiary w sprawach ochrony godności sakramentu pokuty ${ }^{83}$ i $\mathrm{w}$ osądzaniu błędów wiary ${ }^{84}$.

Sposób postę powania. W tej dziedzinie jest jeszcze najwięcej niewiadomych jeśli chodzi o szczegóły, natomiast ogólne zasady zostaly już ustalone.

Przede wszystkim „Kongregacja postępuje dwojakim sposobem: administracyjnym lub sądowym, w zależności od natury rozstrzyganych spraw" ${ }^{85}$. Przepis ten wyraźnie potwierdza dwojaką rolę reformowanego organu władzy papieskiej, a mianowicie jego rolę jako kongregacji i równocześnie trybunału.

Osądzając przestępstwa przeciwko wierze, Kongregacja Nauki Wiary postępuje drogą dociekania sądowego, według norm zwykłego procesu ${ }^{86}$. Ta wielka nowość jest dużym wyłomem w do-

79 MPIS, n. 6; CAREU, n. 34.

80 De Cle rq C., Annotationes, w: Apollinaris 4 (1965), s. 306;

$\mathrm{N}$ a varrete, dz. cyt., s. 647.

81 CAREU, n. 57.

82 CAREU, n. 55.

83 Por. kan. 904 wraz z CAREU, n. 36 i MPIS, n. 8.

${ }^{84}$ Por. kan. 247, \$ 2 i MPIS, n. 7, oraz CAREU, n. 35.

85 MPIS, n. 11; CAREU, n. 39.

36 MPIS, n. 7; CAREU, n. 35.

3 - Prawo Kanoniczne 
tychczasowym prawie, stanowiącym w kan. 1555, § 1,: że „Trybunał Kongregacji Sw. Oficjum postępuje według własnych norm i instytucji, oraz zachowuje sobie właściwe zwyczaje". Normy te i zwyczaje, nie zostały nigdy w całości opublikowane ${ }^{87}$, obecne, są publici iuris i znajdują się w IV księdze Kodeksu Prawa Kanonicznego, tam bowiem należy szukać norm zwykłego procesu.

Dalszy poważny wyłom uczyniony przez MPIS i CAREU w prawie kodeksowym, dotyczy norm postępowania w sprawach ochrony godności sakramentu pokuty. Normy nowego postępowania nie są jeszcze znane, ale obydwa wspomniane dokumenty papieskie mówią, że będą one poprawione (emendatas) i że zostaną podane ordynariuszom do wiadomości. Wiadomo już, że oskarżony będzie mial prawo obrony, nawet przy pomocy wybranego przez siebie adwokata, spośród zatwierdzonych przy Kongregacji ${ }^{88}$. Nic nie wskazuje na to, by tajność procedury w tych sprawach została calkowicie zniesiona, ale ponieważ zostaną o niej poinformowani ordynariusze, nie będą zapewne w przyszłości należały do ścisłego sekretu.

Jeśli zaś chodzi o wewnętrzny regulamin Kongregacji, to papież zapowiada, że dotrze on do publicznej wiadomości za pośrednictwem specjalnej Instrukcji ${ }^{89}$, na którą to Instrukcję w związku $z$ urzeczywistnianą obecnie reformą Kurii Rzymskiej, nie trzeba będzie zbyt długo czekać ${ }^{90}$.

\section{Zakończenie}

Reforma Sw. Oficjum nie jest jeszcze całkowicie zakończona, ale już dziś można twierdzić, że z puktu widzenia normatywnego spełnia ona wszystkie wysunięte pod jej względem postulaty, tworząc z Kongregacji Nauki Wiary organ sprawny i nowoczesny w służbie papiestwa i całego Kościoła. Można chyba wyrazić nadzieję, że także dobór odpowiednich ludzi do tak ważnej Kongregacji, pozwoli jej jeszcze lepiej niż dotychczas wywiązać się z powierzonych jej zadań.

87 O publikacji niektórych norm procesów przeprowadzanych przez Sw. Oficjum, zob. u N a varrete, dz. cyt., s. 637, przypis n. 77.

88 MPIS, n. 8; CAREU, n. 36.

89 MPIS, n. 12 ; CAREU, n. 40.

90 „Dal punto di vista normativo, la riforma non è ancora completa; lo diverrà quando nei prossimi mesi saranno pubblicati i Regolamenti che sono ancora in via di elaborazione da parte delle competenti Com- 


\section{ARGUMENTUM}

\section{REFORMA S. CONGREGATIONIS S. OFFICII}

Auctor in primis indicat praecipua documenta Romanorum Pontificum, constitutionem atque historiam primae Congregationis Romanae spectantia. Deinde, ex actis antepreparatoriis Concilii Oecumenici Vaticani II, refert vota Episcoporum ac Universitatibus Catholicis, quae opportunas mutationes denominationis, structurae et procedurae S. Congregationis $\mathbf{S}$. Officii, ob diversas rationes, postulaverunt. In fine demonstrat, quomodo proposita hac in materia ex toto orbe Catholico allata, in laboribus Concilii, praesertim tamen in activitate legislativa pap. Pauli VI, sc. in Motu Proprio Integrae servandae, in Motu Proprio Pro comperto sane, et in Constitutione Apostolica Regimini Ecclesiae universae, solutionem hodiernis necessitatibus accommodatam invenerunt.

missioni, e che averanno per oggetto la structura ed il funzionamento dei nuovi uffici" powiedzial pap. Pawel VI do Kolegium Kardynalskiego i prałatów rzymskich w dniu 23 grudnia 1967 r. - L'Osservatore Romano, $\mathrm{z}$ dnia 23.12.1967. 